ISSN: 2146-3042

DOI: $10.25095 /$ mufad.579762

\title{
Enerji Yönetiminde Faaliyet Tabanlı Maliyetleme Modeli: Bir Üretim İşletmesinde Uygulama*
}

\author{
Ömer KAVRAR ** \\ Baki YILMAZ ${ }^{* * *}$
}

\begin{abstract}
ÖZET
Medeniyet geliştikçe artan enerji ihtiyacı, azalan doğal kaynaklar ve küresel iklim değişikliği tehdidi gibi nedenlerden dolayl, herkesin enerjiyi verimli ve akılcı bir şekilde kullanılmasının önemi belirginleşmiştir. Enerji maliyetleri çoğu zaman yöneticilerin doğrudan sorumlu olduğu bir maliyet kategorisi olarak değil de düşük önceliğe sahip bir genel üretim gideri olarak ele alınmıştır. Ancak enerji maliyetlerini kontrol altına alarak yönetme bilincine sahip işletmeler, bu konu için düşük bir öncelik atfeden kurumlara nazaran daha rasyonel bir yaklaşım benimsemişlerdir. Bu çalışmanın amacı işletmelerde enerji yönetimi bilinci oluşturmak için modern bir yaklaşım olan faaliyet tabanlı maliyetleme modelinin sağlayacă̆l ayrıntılı enerji verilerini analiz etmektir. Teorik bulgulara destek sağlamak için bir üretim işletmesinde kullanılan enerji kaynaklarının hangi faaliyetler tarafından ne miktarda tüketildiği ve maliyet yapısını nasıl etkilediği araştırılmıştır ve sonuç kısmında çeşitli öneriler geliştirilmiştir.
\end{abstract}

Anahtar Kelimeler: Enerji Yönetimi, Enerji Maliyetleri, Faaliyet Tabanlı Maliyetleme Modeli.

JEL Sinıflandırması: M11, Q40, M41.

\begin{abstract}
Activity Based Costing Model in Energy Management: A Case Study on a Manufacturing Company

\section{ABSTRACT}

As civilization evolves the significance of using energy efficiently, rationally and sustainably has become evident, for reasons such as increased energy needs, diminishing natural resources and the threat of global climate change. Energy costs are often treated as an overhead cost with low priority, not as a cost category where managers are directly responsible. However, enterprises with the awareness of controlling and managing energy costs would have a more rational approach than institutions with a low priority in this respect. The aim of this study is to create energy management awareness in the enterprise by analyzing the detailed energy cost information provided by a modern approach, activity based costing. In order to support the theoretical findings, what amount of energy consumed by which activities and how they affect the cost structure, in a manufacturing enterprise were investigated and various recommendations are developed in the conclusion.
\end{abstract}

Keywords: Energy Management, Energy Costs, Activity Based Costing Model.

Jel Classification: M11, Q40, M41.

Makale Gönderim Tarihi: 20.12.2018

Makale Kabul Tarihi: 23.01.2019

Makale Türü: Vaka çalışmasıı örnek olay)

\footnotetext{
* Bu makale "Enerji Yönetimi ve Muhasebesi: Sürdürülebilir Enerji Yönetimi İçin Faaliyet Tabanlı Maliyetleme Modeli” isimli doktora tezinden üretilmiştir.

** Dr., Selçuk Üniversitesi, İktisadi ve İdari Bilimler Fakültesi, okavrar@ selcuk.edu.tr, ORCID ID: 0000-00033295-6093.

*** Prof. Dr., Selçuk Üniversitesi, İktisadi ve İdari Bilimler Fakültesi, byilmaz@ selcuk.edu.tr, ORCID ID: 00000002-5392-2485.
} 


\section{GíRiş}

Enerji faturaları için gelirlerinin büyük bir bölümünü ayıran tüketiciler ve özellikle de işletme maliyetlerinin önemli bir payını temsil ettiği şirketler, enerji maliyetlerini kontrol altına almaya başlamak ve sürdürmek için güçlü bir motivasyona sahiptir. İşletmeler maliyeti sıfır ya da çok düşük operasyonel değişiklikler ile enerji faturalarında \%10-20 oranında tasarruf edebilir. Sermaye maliyeti iki yıl veya daha az geri ödeme süreleri olan enerji programları genellikle \%20-30 oranında ek tasarruf sağlayabilir. Birçok durumda, enerji maliyetlerini kontrol altına almak, hem enerji tüketimi hem de çevreyi kirletici emisyonların azaltılması ile sonuçlanacaktır (Turner, 2001: 35). Faturalarda \%30'a varan oranlarda tasarruf sağlayabilecek herhangi bir faaliyet kesinlikle herhangi bir şirkette dikkat çekmelidir. Birçok şirket, satışları artırmaya çalışırken para, zaman ve emek harcamaktan çekinmezken, enerji maliyetlerini kontrol altına alarak elde edilecek maliyet tasarruflarını görmezden gelmektedirler.

Son yirmi yılda enerji yönetimi sanayi firmalarındaki destekleyici işlevleriyle önemli ölçüde gelişim göstermiştir. Geçmişte, enerji fiyatlarının düşük ve çok değişken olmadığı dönemlerde enerji maliyetleri, toplam üretim maliyetlerinin sadece küçük bir bölümünü oluşturmaktaydı. İşletmelerin kurumsal yöneticileri için enerji, üretim sürecinde çok düşük hatta hiç önemi olmayan bir girdi faktörüydü. Bundan dolayı, enerji maliyetleri çoğu zaman yöneticilerin doğrudan sorumlu olduğu bir maliyet kategorisi olarak değil de bir genel gider olarak ele alınmıştır (Schulze vd., 2016: 3892).

Bir enerji maliyet tahsisi sistemi ile yönetim, hangi faaliyetlerin ve ürünlerin veya maliyet merkezlerinin daha fazla enerji harcadığını ve en yüksek enerji maliyetine neden olduğunu belirleyebilir. Bu bilgi, karar vericilerin dikkatini büyük enerji kullanılan alanlara odaklayabilir ve bu alanları yeniden tasarlamanın enerji israfını azaltıp azaltmayacağını ve böylelikle enerji verimliliğine sağlayacağı katkıyı değerlendirmede kullanılabilir. Faaliyet tabanlı maliyet (FTM) sistemi, belirli alanlarda veya faaliyetlerde enerji tasarrufu sağlayan yatırımların fizibilitesi için kullanılabilecek gerçek maliyet verilerini de sağlar (Fernandes vd., 1997: 20).

Çalışmanın amacı artan enerji ihtiyacı, azalan doğal kaynaklar ve küresel iklim değişikliği gibi tehditlere odaklanan enerji yönetiminde, faaliyet tabanlı maliyetleme modelinin oynadığı kritik rolü araştırmaktır. Bu amaçla çalışmada ilk olarak enerji yönetiminin kavramı açıklanmış, maliyet unsuru olarak enerjinin özellikleri üzerinde durulmuş ve işletmelerin mevcut enerji yapısının tespit edilmesinde enerji denetiminin rolünden bahsedilmiştir. Daha sonra FTM modelinin kavramsal çerçevesi açıklanmış ve literatür taramasına yer verilmiştir. Son olarak, bir üretim işletmesinin enerji kullanımı ve maliyet analizlerini içeren uygulama yapılmış ve elde edilen bulgular ışığında çeşitli öneriler geliştirilmeye çalışılmıştır. Faaliyet tabanlı maliyetleme yöntemiyle elde edilen ayrıntılı enerji verileri, üretim süreçlerindeki anormalliklerin tespit edilmesine olanak sağlamıştır.

Çalışma enerji odaklı alternatif analiz ve yönetim sistemleri geliştirilmesine katkı sağlaması, tüketilen fosil enerji kaynakları ile çevre kirliliği arasındaki ilişkiye dikkat çekmesi ve enerji giderlerinin bir üretim işletmesinin maliyet yapısında oynadığı rolü ortaya koyması bakımından önem arz etmektedir. 


\section{ENERJI YÖNETIMI}

Enerji kaynaklarının mevcudiyetindeki sınırlılıkları göz önünde bulundurursak dünya genelinde artan enerji talebi enerji maliyetlerinin yükselmesine neden olmaktadır. Yakıtların ve elektriğin ucuz olduğu alanlarda bile, kaynakların verimli ve mantıklı kullanımının kullanıcıya, milletine ve genel olarak insanlığa fayda sağlayacağı açıktır. Enerji şirketleri açısından ise enerji yönetimi, yeni enerji santralleri ve ilgili altyapı yatırımlarında yapacakları sermaye harcamaları için gerekli zamanı sağlar (Smith ve Parmenter, 2016: 28).

Şirketlerin etik, sosyal ve çevresel konulardan sorumlu tutulması ve kuruluşların sürdürülebilir bir şekilde yönetilmesi konusunda farkındalığın arttırılması gereklidir. Çevresel kaynakların sınırlı olduğu ve gelecek nesiller için korunması gereği genel kabul gören bir durumdur. $\mathrm{Bu}$ nedenle şirketlerin çevresel maliyetlerin ölçülmesi ve raporlanması için sistemler geliştirmeye ihtiyaç duyulmaktadır.

Şekil-1'de bir üretim işletmesinde enerji ve malzeme akışının çevresel etkileriyle birlikte basitleştirilmiş bir model ile görselleştirilmektedir. Buna göre hem üretim hem atık yönetimi için girdi olarak kullanılan enerji ve malzeme çevreye doğrudan, müşteriye ürün olarak veya geri dönüşüme atık olarak çıktıya dönüşmektedir. Bazen de doğrudan girdi olan enerji dönüşüm sürecine tabi tutularak üretim merkezlerinin ihtiyacını karş1lamak üzere bir başka forma dönüştürülürler. Her adımda enerjinin çevreye verdiği zararı tespit edebilmek ve süreci kontrol altına alabilmek için enerji akışları tanımlanmalı ve ölçülmelidir. Bu sayede malzeme ve enerji kullanımının azaltılması, atıkların yanı sıra enerji kayıplarının azalması gibi olumlu ekolojik etkiler ortaya çıkacaktır. Bu aynı zamanda malzeme, enerji ve elden çıkarma maliyetlerinde tasarruf sağlayabilir ve sürdürülebilir bir ekonomi ve çevresel yönetimi teşvik edebilir (Sygulla vd., 2011: 1-4).

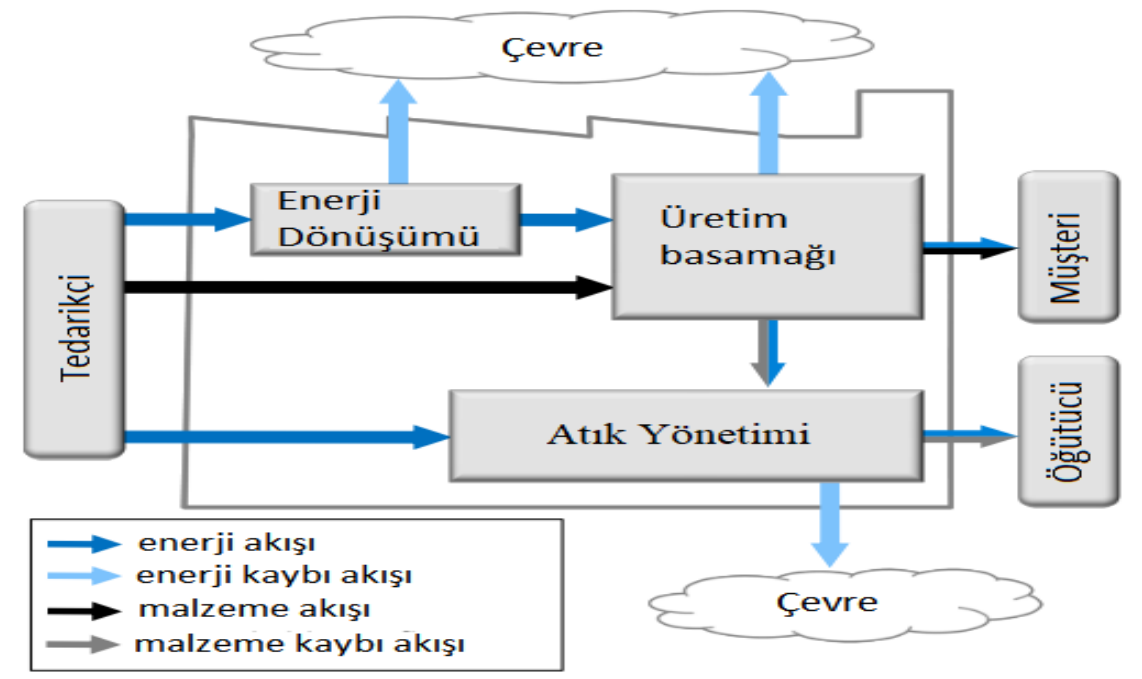

Kaynak: (Sygulla vd., 2011: 4)

Şekil 1. Basitleştirilmiş Enerji Akışı Modeli

Çevresel maliyetler ve bunların nedenleri hakkında bilgi sahibi olmak, yöneticilerin kıt çevresel kaynakların ve emisyon kirleticilerinin kullanımını en aza indirecek ve daha hassas 
çevresel kararlar alabilmeleri için süreçleri yeniden tasarlamaları gereken bilgileri sağlayacaktır (Dury, 2018: 12). Etkin bir enerji yönetimi stratejisi düşük karbon emisyonuna sahip kaynakların etkin bir şekilde dağıtılmasını ve aktif dağııım sisteminin ekonomik olarak işlemesini sağlayabilir (Xiang vd., 2015: 542). Özellikle tüketilen fosil enerji kaynakları ile çevre kirliliği arasındaki yüksek korelasyon, enerji-yoğun çalışan şirket yöneticileri için üzerinde önemle durulması gereken konuların başında gelmektedir.

\subsection{Bir Maliyet Unsuru Olarak Enerji}

Fizikte enerji iş yapabilme yeteneği olarak tanımlanır. İşletme yönetiminde ise enerji (veya enerji kaynakları), üretimi, tedariki, atık bertarafı vb. maliyetlere neden olan bir üretim faktörüdür (Annett ve Uwe, 2012: 129-130). Enerji ile ilgili doğru tanzim edilmiş bir maliyet bilgisi sağlamak için, enerji ve enerji tüketiminin özellikleri ve bunların kavramsal olarak ele alınış şekilleri iyi algılanmalıdır. Bir üretim ve maliyet faktörü olarak enerji bazı özelliklere sahiptir (Wang, 2013: 38).

i. Tüketimin rasyonalitesini içerir. Bazı ürünlerin üretilmesinde gerekli olan miktarda enerjiden azının veya çoğunun tüketilmesi söz konusu olmamalıdır. Makul seviyede enerji ihtiyacını belirlemek için muhasebe kontrolünde iyileştirmeler gereklidir.

ii. Tüketim standartlarına uygunluğu içerir. Belli ürünlerin üretimi için harcanan enerji, ilgili gerekliliklere uygun olmalıdır ve bu nedenle maliyet, kalite ve miktar arasındaki ilişki kapsamlı olarak ele alınmalı ve kontrol edilmelidir.

iii. Tüketim tasarrufu özelliğine sahiptir. Yani, mümkün olan en düşük kaynak tüketimi ile azami ekonomik faydalar elde edilebilir, ancak tüketim tasarrufu, ürün kalitesini ve performansını azaltmadan ön plana çıkarılmalıdır.

iv. Maddi nesnelerin fiziksel birimleriyle olan ilişkisini göstermektedir. Enerji maliyeti, enerji tüketim biriminin değişimi ile birlikte eşanlı olarak değişir ve bu nedenle enerji tüketimi birimine yakındır.

İşletmeler rekabetçi piyasalarda faaliyetlerine devam ederken, üretim maliyetleri genellikle ikincil kabul edilir. Üretim marjlarının hayati önem taşıdığı oldukça rekabetçi piyasalarda bile, işçi ve malzeme maliyetlerinin azaltılması üzerinde odaklanma olasılığı yüksektir. Enerji genellikle kontrol edilemeyen bir ek yük olarak kabul edilir veya düşük bir önceliğe sahiptir (ETSU vd., 1999: 1). Ancak gerçekte enerji maliyetlerini kontrol altına alma bilincine sahip işletmeler, bu konuda düşük bir öncelik atfeden kurumlara nazaran daha rasyonel bir yaklaşım göstermiş olacaklardır.

Organizasyonlarda bir üretim faktörü olarak kullanılan enerjinin işletme maliyeti içindeki payı sektörden sektöre farklılık gösterir. Az ya da çok enerji maliyetleri hammadde girdisinin aksine kontrol edilebilmektedir. Enerji tüketimlerinin sürekli izlendiği bir organizasyonda oluşan enerji yükü her zaman aynı değildir. Üretimin olmadığı zamanlarda veya üretimin olduğu ancak değişik kapasitelerde faaliyet gösterildiği durumlarda oluşan

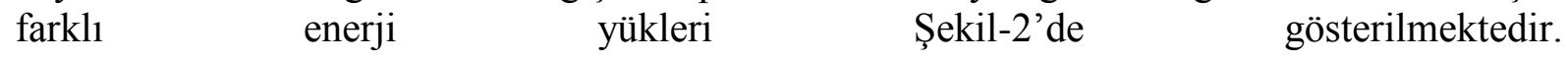




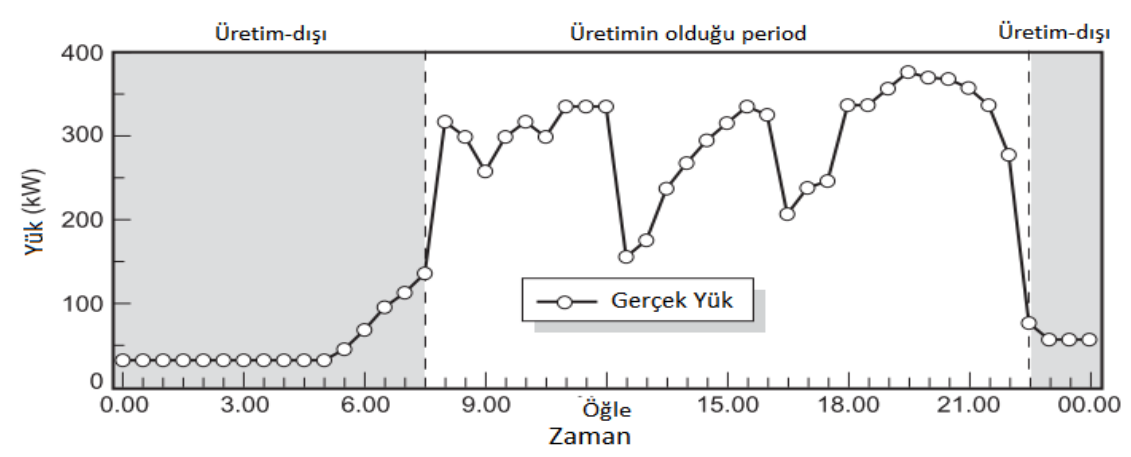

Kaynak: (ETSU vd., 1999: 7)

Şekil 2. Bir İşletmede Oluşan Elektrik Yükünün İzlenmesi

Herhangi bir ürünün toplam maliyetine benzer şekilde, işletmelerin değişen yüklerde kullandıkları enerjinin maliyeti hem sabit hem de değişken maliyetlerin birleşiminden meydana gelmektedir ve her iki bileşeni de azaltmak için etkili enerji yönetimi teknikleri kullanılabilir (Tangram, 2010: 4).

Toplam Ürün Maliyeti $=$ Sabit Maliyetler $+($ Üretim Hacmi x Birim Değişken Maliyet $)$

$\mathrm{Bu}$ eşitliğin enerji maliyetleri açısından ifadesi aşağıdaki gibidir.

Toplam Enerji Kullanımı = Ana Yük + (Üretim x Özgül Enerji Tüketimi)

İşletmede üretimin gerçekleşip gerçekleşmediğine bakılmaksızın bir 'Ana Yük" oluşur ve çıktı miktarına bağlı olarak değişmez. "Özgül Enerji Tüketimi” (ÖET) her birim bitmiş ürünü işlemek için kullanılan enerji miktarının bir ölçüsüdür ve standart bir maliyet sisteminde birim değişken maliyete benzer. Ana yük ve ÖET arasındaki ilişki Şekil-3'te gösterilmiştir.

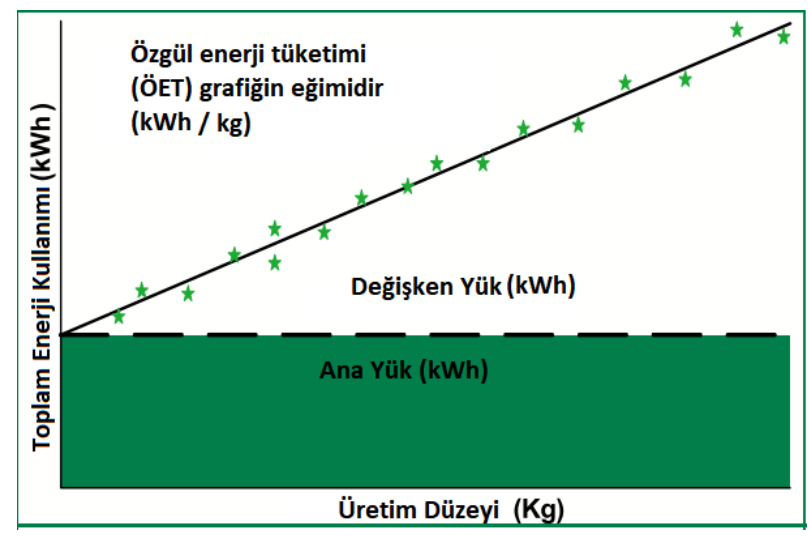

Kaynak: (Tangram, 2010: 4)

Şekil 3. Ana Yük ve Değişken Yük

Grafikten görüldügü üzere, toplam enerji kullanımının bir bölümü üretim düzeyindeki değişmelere (1 kg veya 1 ton) bağlı kalmaksızın sabit olan ana yük miktarından oluşmaktadır. Diğer taraftan üretim hacmine göre artan oranda bir maliyet unsuru vardır ki burada değişimin boyutunu özgül enerji tüketimi ve üretim düzeyi belirlemektedir. Toplam enerji maliyeti bu 
iki bileşenin herhangi bir üretim seviyesinde toplanmasıyla elde edilir. Herhangi bir maliyet yönetimi sürecinde olduğu gibi, toplam enerji kullanımını azaltmak için iki yöntem vardır:

$>\quad$ Sabit maliyetleri azaltmak için ana yükün azaltılması.

$>\quad$ Değişken maliyetlerini düşürmek için ÖET'yi düşürmek.

$\mathrm{Bu}$ temel maliyet bilgisinden sonra karar alma sürecinde daha ayrıntılı maliyet verilerine ihtiyaç duyulmaktadır. Bir organizasyonda mevcut enerji durumunun tanımlanması, problemlerin tespit edilmesi ve iyileştirme tedbirlerinin alınabilmesi için ilk adımı enerji denetimi oluşturmaktadır.

\subsection{Enerji Denetimi}

Bir enerji denetiminin amacı, enerji kullanımını ve/veya maliyeti düşürmek için firsatları belirlemektir. Düzgün bir şekilde yapılan bir enerji denetimi, enerji yönetimi işini başlatmanın ilk adımıdır. Bir denetim olmadan bu işi başlatmak, bir şirketin denetimcisinin bütçesini bir önceki yılın mali dengesini bilmeden formüle etmesi gibi olur ve başarısız olma olasıllğı da yüksektir (Thollander ve Palm, 2013: 101). Enerji denetimi finansal denetimlerin aksine enerji verimliliği sürecinin sonu olarak değil bir enerji yönetimi programı kurmanın ilk adımı olarak görülmelidir. Dahası belirli aralıklarla tekrarlanması zaman içinde unutulan tedbirlerin gözden geçirilmesine olanak tanır.

Enerji analizi, tesislerde enerji kullanımının dağılımını, enerji kullanım endeksini, tarihsel karşılaştırmaları, maliyet analizini, işletme ve bakım prosedürleri üzerindeki etkileri ve analiz gerektiren potansiyel sermaye yoğun iyileştirmelerin belirlenmesini içerir (ASRAE, 2015: 36). Bir işletmede yapılacak enerji denetiminin seviyesi, işin karmaşıklığı, enerji kaynaklarının çeşitliliği, tesisin büyüklüğü ve yapısı ile yakından ilgilidir.

\subsection{Enerji Maliyetlerinin Faaliyetler Üzerinden İzlenmesine Duyulan İhtiyaç}

Enerji yöneticisi için en zor problemlerden biri, enerji giderlerinin genel giderlerin bir parçası olarak muhasebeleştirildiği bir tesisin enerji maliyetlerini azaltmaya çalışmaktır. $\mathrm{Bu}$ durumda, münferit yöneticiler ve denetçiler enerji maliyetlerini kontrol etmek için kendilerini sorumlu görmezler. Bunun nedeni, toplam şirket yükünün bir parçası olan maliyetleri azaltmakta doğrudan bir fayda görmemeleridir. Bu soruna en iyi çözüm, üst yönetimin enerji maliyetlerini şirket veya tesiste "maliyet merkezlerine" indirmesidir. Enerji masrafları aynı malzeme ve işçilik masraflarında olduğu gibi üretim merkezlerine ayrı ayrı yüklendiğinde her bir üretim merkezinin maliyet etkinliğini gözeten yöneticilerin enerji maliyetlerini doğrudan kontrol etme güdüsü oluşacaktır (Capehart vd., 2003: 28).

Enerji yönetimi sistemi tarafindan etkinleştirilen her organizasyonel birim (örneğin, departmanlar veya faaliyetler), gerçekte sorumlu olduğu enerji gideri ile yükümlü olmalıdır. Enerji yönetiminin amacı kişinin davranışı (sebep) ile bu davranış sonucu ortaya çıkan enerji maliyeti (sonuç) arasındaki açı̆̆ı kapatmaktır. Diğer bir değişle bireylerin verimli olmayan enerji kullanma alışkanlıkları sonucu ortaya çıkan yüksek maliyetleri en uygun seviyeye getirmeye odaklanır. Toplam enerji maliyetleri, işgal ettiği alan bazında birimlere tahsis edilmesi, enerji yönetiminin amacını yitirmesine neden olur (Henze, 2001: 105). Bu yetki ve sorumluluk ayrılığı, enerji harcamalarının yönetimini ve kontrolünü kolaylaştırır ve 
maliyetleri düşürme çabalarının etkinliğini artırır. Maliyetleri azaltma çabaları hangi birim tarafından ne oranda yapıldığı tespit edilirse, tanınmanın sağlanması ve dolayısıyla ödül mekanizmasının çalışması mümkün olabilir. Bu işletmenin tüm birimlerinde maliyet azaltma adına daha fazla çaba gösterilmesiyle sonuçlanabilir. Yüksek enerji maliyetlerine neden olan faaliyetleri tespit etmek için daha fazla araştırmaya ihtiyaç duyulmaktadır.

\section{FAALIYET TABANLI MALIYYTLEME MODELI}

Yöneticiler, araştırma ve geliştirme, bütçeleme, üretim planlama, fiyatlandırma ve müşterilere sunulan ürün veya hizmetler hakkında karar vermek için maliyet muhasebesi bilgilerini kullanırlar (Horngren vd., 2015: 24). Bu ihtiyaçların giderilmesinde alışılagelmiş maliyet muhasebesi bilgi sistemlerine daha doğru bilgileri zamanında verebilecek yeni sistemlerin ilave edilmesi rekabet avantajı kaynağı olarak görülmüştür (Hofmann ve Bosshard, 2017: 712). Faaliyet tabanlı maliyet (activity based costing) sistemi de bu maliyet sistemlerden biri olarak muhasebe bilgi sistemleri içerisinde yerini almıştır (Unutkan, 2010: 87).

Modern bir muhasebe yöntemi olan faaliyet tabanlı maliyetleme (FTM), geleneksel maliyet muhasebesinin toplam maliyetlerin azaltılmasına katkı sağlayamaması ve genel giderlerin hatalı dağıtılması nedeniyle maliyetlerdeki çarpıklık gibi iki temel sorunu gidermek için bir araç olarak geliştirilmiştir. Faaliyete tabanlı maliyetleme, bir üretim sistemi veya bir kuruluştaki faaliyetleri tanımlayan bir muhasebe metodolojisidir (Johnson'dan aktaran Kim, 2017: 20). Sistemin nasıl tasarlandığına bağlı olarak bir FTM sistemi çeşitli amaçlarla uygulanabilir.

Bir işletme FTM sistemi uygulamaya karar verdiğinde, faaliyetlerin tanımlanması ve bu faaliyetler tarafından tüketilen kaynakları belirlenmesiyle işe başlar. Faaliyet tabanlı maliyetleme sistemi temel olarak aşağıdaki dört adımdan oluşmaktadır (Davis ve Davis, 2013: $368)$.

1. Aşama: Bir FTM sisteminin uygulanmasındaki ilk büyük adım, sistemin temelini oluşturacak faaliyetleri tanımlamaktır. Faaliyetler, kaynak tüketimine neden olan birçok farklı görev, faaliyet veya iş biriminin bir araya getirilmesinden oluşur

2. Aşama: Faaliyetler tespit edildikten sonra, belirli bir süre boyunca tüketilen kaynakların maliyeti her faaliyete tahsis edilmelidir. Amaç, organizasyonun her bir faaliyetine ne kadar harcama yaptığını belirlemektir. Bu, birinci aşama tahsisi olarak anılır, çünkü maliyetler, maliyet objelerine dağıtılmadan önce faaliyet havuzlarına yüklenir.

3. Aşama: Her faaliyet maliyet merkezine eklenen maliyetleri ürünlere tahsis etmek için, bir maliyet sürücüsü seçilmelidir. Seçilen faaliyet sürücüleri her maliyet havuzundaki maliyetler ile mamuller arasında iyi bir açıklama sağlamalıdır. Sürücü seçimi daima modelin doğruluğunu belirleyecektir.

4. Aşama: Faaliyet tabanlı maliyet uygulamasının dördüncü ve son adımına ikinci aşama tahsisi denir. İkinci aşama tahsisinde, genel üretim giderlerini ürünlere ve müşterilere yansıtmak için faaliyet oranları kullanılır. 
Genel olarak bir FTM sisteminde maliyetlerin ürünlere ve diğer maliyet nesnelerine dört aşamada tahsis edilmesi süreci hakkında daha iyi bir fikir edinmek için Şekil-4 görsel bir perspektif sunmaktadır.

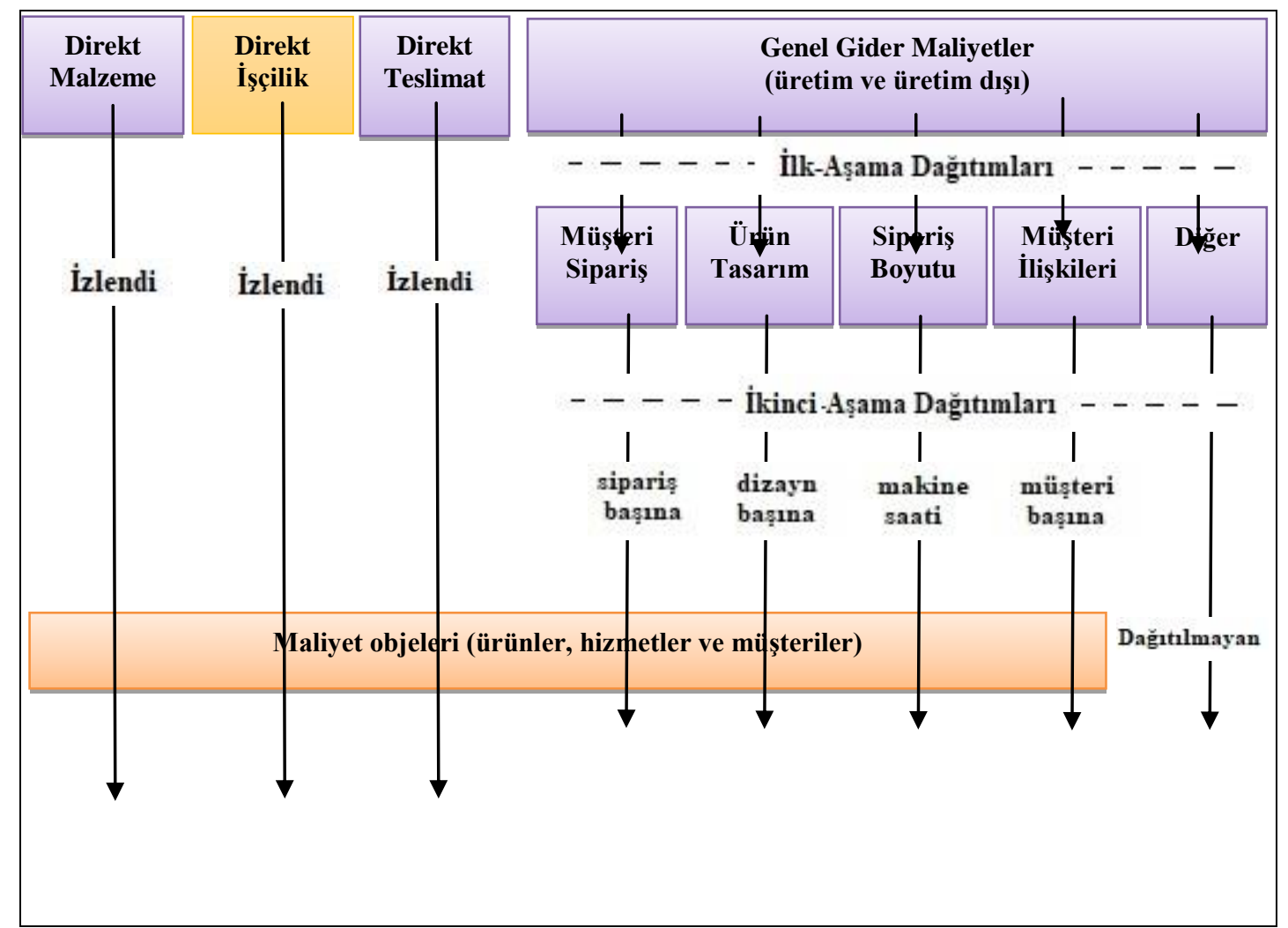

Kaynak: (Garrison vd., 2018: 323)'den uyarlanmıştır

Şekil 4. Faaliyet Tabanlı Maliyetleme Modeli

FTM'ye göre ürünlere tahsis edilen genel gider maliyetleri, toplam genel gider tutarı ile aynı değildir. Çünkü FTM'de organizasyonun sürdürülebilirliği için yapılan faaliyetlerden kaynaklanan maliyetler gibi üretimden kaynaklanmayan (üretim dışı) maliyetler dikkate alınmamaktadir.

Genellikle bir işletmede tüm genel üretim maliyetlerini dikkate alarak uygulanan model, bir kaynak maliyeti olan enerji giderlerinin faaliyetlere tahsis edilmesi için uyarlanabilir. Aşağıdaki tartışma süreci nispeten kolay görünse de, gerçekte karmaşık, zaman alıcı bir çabayı gerektirmektedir. Bununla birlikte sistem devreye girdiğinde karar vericiler, iyileştirilmiş bilgilerden maksimum seviyede faydalanacaktır.

\section{Literatür İncelemesi}

Yabancı literatürde yer alan çok sayıda bilimsel çalışma enerji yönetimi ve muhasebe konusu için destekleyici bir arka plan sağlamasına rağmen yerli literatürde enerji yönetimi hakkında kitaplar, hakemli dergiler ve bilimsel makaleler gibi kaynakların sınırlı olduğu görülmektedir.

Yerli çalışmalarda en öne çıkan çalışma (Kırlı ve Kulu, 2016) tarafindan "Enerji Yönetimi ve Enerji Muhasebesi" isimli makaledir. İşletmelerin karlılıklarını ve verimliklerini arttırmalarında enerjinin optimum kullanımının önemli olduğu ve bu amaca ulaşmak içinde enerji yönetimi uygulamalarından yararlanılması gerektiği hipotetik bir örnekle incelenmiştir. 
Enerji yönetimi uygulamalarında gerekli tedbirlerin alınıp, yeni politikaların üretilmesinde önemli bir alt bilgi sistemi olan enerji muhasebesinin en büyük katkıyı sağlayacağı sonucuna ulaşılmıştır. Diğer bazı çalışmalarda enerji muhasebesi araştırmaların ana odağı olmamakla birlikte, (Karslı vd., 2011) çalışmasında enerji muhasebesinin, diğer maliyet muhasebesi uygulamalarında olduğu gibi enerji yönetimi bakımından son derece önemli bir araç olduğunu belirtmiştir. (Bozkurt ve Karataş, 2011) çalışmalarında enerji sektöründe muhasebe standartları ile vergi mevzuatının farklılık gösterdiği hususlara değinmiştir. (Üçüncü, 2016), (Kavak, 2005), (Topallı, 2012) ve (Dizkırıcı, 2012) çalışmalarında, sanayide enerji verimliliğinin arttırılması için alınması gereken tedbirler arasında enerji muhasebesinden bahsetmektedirler. (Çakal, 2006) ve (Elektrik İşleri Etüt İdaresi Genel Müdürlüğü, t.y.) çalışmalarında enerji muhasebesinin iyi organize olmuş bir enerji yönetim sistemine kılavuzluk yapacağını vurgulamışlardır.

Yabancı literatüre baktı̆̆ımızda; (Hyman, 1976) hizmet muhasebesi ve enerji politikalarını ele almaktadır. 1970'li yılların sonunda (Boyles, 1979), enerji maliyeti için muhasebe disiplininin ön plana çıktığını vurgulamış ve çalışmasında enerji verilerini raporlamada karşılaşılan problemlerin temel çerçevesini ortaya koymuştur. (Cornwall ve California Energy Extension Service, 1984) enerji verilerinin nasil organize edilip sunulacağıyla ilgili enerji verilerini planlama, kayıt tutma ve enerji tasarrufu ile ilgilenenlere enerji muhasebesi metotları ile ilgili bilgiler vermektedir. (A.E.Eagles ve J.Claret, 1990) Watt komitesi tarafından yayınlanan enerji kullanımının değerlendirmesi raporunda bazı basit prosedürlerin uygulanmasıyla küçük işletmelerde enerji kullanımının daha büyük bir kontrol düzeyi sağlanabileceği vurgulanmaktadır. Yine aynı raporda (A.Melvin vd., 1990), ulusal ve kabul edilmiş ilkelere dayanan kapsamlı bir plan analizi ve enerji muhasebesinin hükümet seviyesinde daha net bir şekilde açıklanması gerektiğine dikkat çekmektedir. (J.K.Jacques vd., 1990), enerji muhasebesi ve denetimi için ölçüm ve planlama metotlarındaki problemleri incelemektedir. (Nelson, 1994), bireysel tesis bazında enerji tüketimini azaltılması ile ilgili çalışmalarda hatalı sonuçlara bir alternatif bakış açısı getiren çalışmasında enerji mühendislerine yönelik çeşitli hesaplama ve izleme teknikleri ve enerji muhasebesini işlevi ele alınmıştır. (Fernandes vd., 1997), geleneksel maliyetleme yöntemleri ile göz ardı edilen enerji maliyetlerini faaliyet tabanlı maliyetleme yöntemini kullanarak, bir üretim işletmesinde uygulanmalı bir örnekle açıklamıştır. Enerji maliyetlerini yönetmeninin bir anahtarı olarak muhasebenin nasıl kullanılacağı ve mevcut teknikler, (California Energy Commision, 2000) tarafından ele alınmıştır. (Tripp, 2007), Enerji Mühendisliği ve Teknolojisi Ansiklopedisi’nde yer alan "Muhasebe: Tesislerde Enerji Kullanımı" makalesinde, enerji izleme ve hedefleme, geleneksel performans endekslerinde veya enerji yoğunluğunda olası eksiklikleri, enerji performans analizi konularını ele almıştır. Enerji tasarrufu ve tüketimi azaltma üzerine yapılan bir çalışmada (Wang, 2013), enerji muhasebesinin kapsamı, amacı ve unsurlarının teorik temeline yer vermiştir.

\section{BİR ÜRETIM İŞLTMESINDE ENERJI MALIYYETLERİ ANALİİ}

Çalışmanın bu bölümü teorik çerçevesini desteklemek amacıyla bir üretim işletmesinde enerji maliyetlerinin FTM yöntemine göre analizini ortaya koymaya yönelik bir uygulamayı içermektedir.

\subsection{Araştırmanın Amacı ve Önemi}

Bu uygulamanın temel amacı bir üretim işletmesinin enerji kullanımını FTM modeli ile analiz ederek, karar alma sürecine ve sürdürülebilirliğe katkı sağlayabilecek ayrıntılı 
maliyet verileri elde etmektir. Bir diğer amaç FTM ile elde edilecek detaylı maliyet verilerinin enerji yönetiminde uygulanabilecek rasyonel bir yaklaşım olup olmadığını incelemektir. Bu araştırma ile işletme yöneticileri için enerji tüketimi uygulamalarını kontrol etme ve yönetme bilinci oluşturmaya ve enerji yönetimi sistemlerini daha fazla kaynak ışı̆̆ında hayata geçirmelerine katkı sağlaması beklenmektedir.

$\mathrm{Bu}$ çalışma, artan enerji fiyatları ile birlikte giderek önemli hale gelen enerji masraflarının bir üretim işletmesinin maliyet yapısında oynadığı rolü ortaya koyması ve enerji odaklı alternatif analiz ve yönetim sistemlerinin geliştirilmesine katkı sağlaması açısından ayrı bir öneme sahiptir. FTM modeli, enerji yönetimi için sağlayacağı veriler ile verimliliğin arttırılması ve maliyet tasarrufunun sağlanmasına katkıda bulunurken, enerji verimliliğindeki boşlukları açık ve görülebilir kılan bir muhasebe tekniği olarak farklı bir enstrüman ortaya koymaktadır.

\subsection{Araştırmanın Kapsamı}

$\mathrm{Bu}$ araştırma Konya ilinde faaliyet gösteren bir üretim işletmesinde 2017 yllına ait enerji girdilerinin üretim süreçleri üzerindeki etkisini göz önünde bulundurarak, enerji maliyet yapısının en uygun hale getirilmesi için yapılan maliyet analizini kapsamaktadır. Bu kapsamda uygulama, imalat firmasında ortaya çıkan enerji maliyetlerini FTM modeline göre incelenmesini ve sonuçlarının klasik maliyetleme ile karşılaş̧ııılmasını içermektedir.

\subsection{Araştırmanın Yöntemi ve Tekniği}

Analizimizde ihtiyaç duyulan nitel ve nicel verilere ulaşmak için örnek olay incelemesi yöntemi kullanılmıştır. Etkin bir maliyet kontrol programı yürütmek için enerji denetimi ilk görevlerden biri olmuştur. Uygulama işletmesinde yaptı̆ııız Enerji Denetimi, katılımcı gözlem, görüşme, doküman incelemesi ve arşiv kayıtları gibi veri toplama tekniklerini içermektedir.

FTM analizinde çalışanlarla yapılan görüşmeler veya doğrudan gözlemlerden yararlanılmıştır. Tesis ziyareti öncesi hazırladığımız sorular ve analizimiz için ihtiyacımız olan verilerden oluşan enerji denetimi anketi üç gruptan oluşmaktadır. Bunlar; Organizasyon hakkında temel bilgiler, Enerji denetimi ile ilgili sorular ve Enerji analizi verileri olmak üzere üç başlıkta toplanmıştır.

\section{4. İşletme Hakkında Genel Bilgiler}

1974 yıllnda temelleri atılan işletmenin 2014 y1lı itibari ile $11.400 \mathrm{~m}^{2}$ kapalı 44.000 $\mathrm{m}^{2}$ açık alanda kuzine soba başta olmak üzere, her türlü katı yakıtlı sobanın üretimini yapan, ulusal ve uluslararası piyasalarda faaliyet gösteren, sektöründe öncü firmalarından biridir. İşletme ISO 9001 kalite yönetim sistemi belgesi, TSE Türk standartlarına uygunluk belgesi ve CE Avrupa'ya uygunluk belgelerine sahiptir. Üretim ve yönetim işlerinin tek bir fabrikada gerçekleştiği işletmede üretimde 73 işçi, 6 idari personel ve 4 pazarlama personeli olmak üzere toplam 83 personel çalışmaktadır.

Örnek uygulama firması seçilirken özellikle enerji verilerinin ön plana çıktı̆̆ bu araştırmada işletmenin geçmişe dönük enerji tüketimi ve harcama kayıtları ile makine saatlerinin düzenli tutulmuş olması belirleyici olmuştur. $\mathrm{Bu}$ sayede enerji maliyet sürücüleri kullanılarak FTM'ye dayalı bir enerji kaynağı maliyet tahsisi oluşturulması mümkün olmuştur.

Organize sanayi bölgesinde yer alan soba işletmesinde 6 grupta, 49 farklı modelde iç ve dış piyasalara dönük katı yakıtla çalışan soba üretilmektedir. İşletmenin kullandığı enerji 
çeşitleri arasında elektrik ve kömür enerjisi yer almaktadır. Geleneksel maliyetleme modelinin benimsendiği belirtilen işletmede yapılan incelemeler sonucu genel üretim giderleri ürün maliyetlerine geçmiş deneyimlerden ve cari girdi fiyatlarından yararlanılarak önceden tahmin edilen oranlara göre yansıtıldığı gözlemlenmiştir.

\subsection{Faaliyet Tabanlı Maliyetleme Modeli Uygulaması}

Katı yakıtla çalışan soba üretimi yapan işletmenin enerji kullanım yapısı ve maliyet analizi için kullanılacak faaliyet tabanlı maliyetleme modeli aşağıdaki dört adımdan oluşmaktadır.

\subsubsection{Faaliyetlerin Belirlenmesi}

Tam bir FTM analizinde, enerji kullanımı ilk aşama maliyet dağıtım anahtarlarından sadece biri olacaktır. Bu uygulamada sadece enerji kullanımı incelendiğinden enerji maliyeti sürücüsünü Şekil 5'teki gibi altı enerji kaynak kullanımı grubu için maliyet sürücülerine ayrılmıştır. Analizimiz için ilk aşamalı enerji maliyeti sürücüleri tüketilen kömürün kg miktarı ve tüketilen elektriğin $\mathrm{kWh}$ 'leridir.
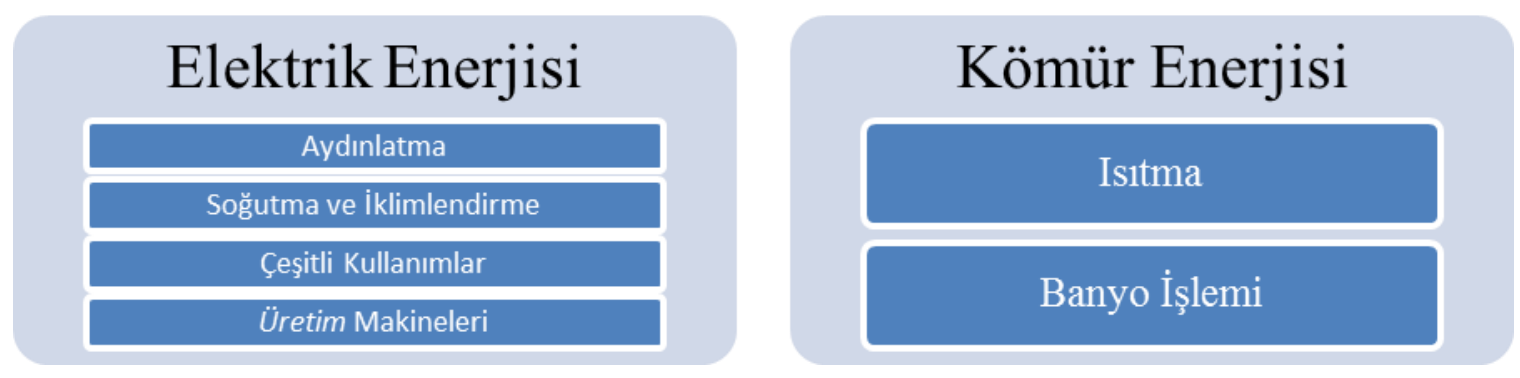

Şekil 5. Enerji Maliyetlerinin 6 Kaynak Grubuna Ayrılması

Kaynak kategorisinin toplam maliyetini bulmak ve daha sonra çeşitli faaliyetlere nasıl bölüştüreceğine karar vermek yerine, çeşitli faaliyetler tarafından kullanılan kaynağın yerini belirlemek ve doğrudan faaliyet maliyet havuzlarının bileşenlerini hesaplamak en kolay yoldur. Firmamızdaki dört ana faaliyeti yönetim ofisi, imalat katı, emaye bölümü ve depolamadan oluşmaktadır.

Enerji maliyetlerinin tahsisinde çok sayıda ve değişik modelde soba üreten işletmede FTM sisteminin uygulanabilirliğini basitleştirmek amacıyla ikinci aşama maliyet tahsisinde üretilen her birim mamul için tekrarlamak yerine sekiz maliyet merkezlerinin seçilmesine karar verilmiştir. $\mathrm{Bu}$ maliyet merkezleri sac kesim, presleme, puntalama, banyo, emaye kaplama, fırınlama, dökümhane ve montaj işlemleridir. Uygulama örneğimizde enerji maliyetlerinin tespiti için uyarlanmış FTM modeli Şekil-6' da yer almaktadır. 


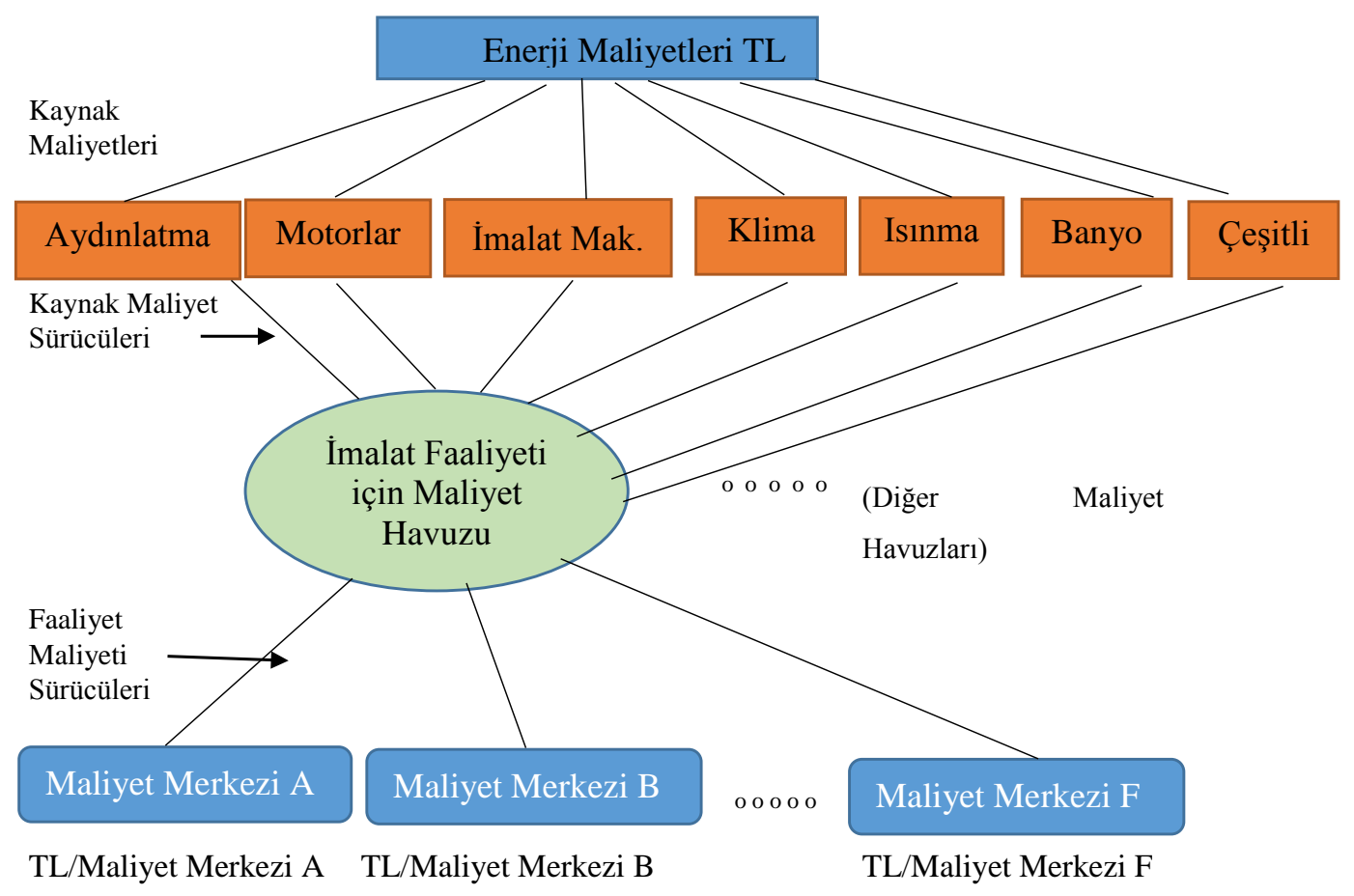

Şekil 6. Firmanın Enerji Maliyet Tahsisi

$\mathrm{Bu}$ maliyet tahsis verileri işletmede hangi maliyet merkezlerinin en fazla enerji kaynağını tükettiğine dair bir fikir verecektir. Şirketin bir merkezin tüketimini belirlemesiyle bu merkezlerde olası maliyet azaltıcı tedbirlerin alınıp alınmamasıyla ilgili karar verebilir.

\subsubsection{Maliyetlerin Faaliyet Havuzuna Yüklenmesi}

Analizimizde yer alan soba işletmesinde faaliyetler belirlendikten sonra ilk görevimiz, altı kategorinin her biri için gerçek maliyetlerini belirlemektir. Bu tespit temel olarak tesis için ayrıntılı bir enerji denetimi ve enerji analizi yapılmasını gerektirmiştir. İlk olarak firmanın 2017 yllına ait enerji faturaları incelenmiştir.

İşletmenin 2017 yllı için tükettiği 1.398.884,76 kWh elektrik enerjisi için toplam maliyeti $395.623,44$ TL ve tükettiği $171.480,00 \mathrm{~kg}$ kömür enerjisi için toplam maliyeti 111.675,00 TL olmuştur. 2017 yllı boyunca elektrik enerjisi için kWh başına 28.28 kuruş ve kömür enerjisi için kg başına 65.12 kuruş olarak hesaplanan bu birim maliyetler takip eden tüm çalışmalarda altı enerji kaynağı maliyet kategorisinin maliyetini hesaplamak için kullanılacaktır (Tablo-1).

\subsubsection{Aydinlatma}

Fabrikanın gün 1şığı aydınlatma çatı sistemi yer almaktadır. Günün aydınlık olduğu saatler içerisinde güneşin doğuşundan batışına kadar olan süre doğal gün ışığından maksimum faydalanmayı sağlayan sistem, aydınlatılmak istenen mahalde doğal aydınlatmayı sağlamaktadır. Bu aydınlatma sistemi ile fabrikanın aydınlatma enerji tüketimi büyük ölçüde 
azaltmaktadır. Çatı aydınlatma sisteminin yetersiz olduğu zamanlar ve birimler için kullanılan lambaların ayrıntılı bir envanteri çıkarılmıştır.

Genel ofiste yer alan idari personel ve yönetim odaları farklı türde aydınlatma ünitelerine sahip olduklarından, genel ofisin aydınlatma için enerji kullanımları ve maliyetleri ayrı ayrı hesaplanmıştır. Daha sonra her faaliyet tarafından tüketilen $\mathrm{kWh}$ kullanılarak ilk aşama kaynak maliyet sürücüleri olarak beş faaliyete ayrılmıştır. Montaj, presleme ve sac kesim alanını içeren imalat alanında aydınlatma toplam 331 adet 54-watt'lık A sınıfı enerji verimli floresanla sağlanmıştır. Dönem boyunca yaklaşık 578 saat çalıştırıldılar. \% 20'lik bir balast tüketime eklendikten sonra, üretim alanı faaliyeti $12.393 \mathrm{kWh}$ kullanmış ve böylece 3.504,74 liralık bir aydınlatma maliyeti olmuştur. Genel ofiste yönetim kurulu üyelerinin odaları ve led panel aydınlatma ile aydınlatılırken idari personelin odaları ve lobi floresanlı çift parabolik armatür kullanılmıştır. Bu hesaplamalar Tablo-2'de yer almaktadır.

\subsubsection{Soğutma ve İklimlendirme}

Genel ofis bölümünde bulunan 7 odada 34120 Btu'luk saatte $3,6 \mathrm{~kW}$ güç çekimine sahip kaset tipi split klima bulunmaktadır. Ünitelerin yaz dönemi boyunca belirli aralıklarla tam yüke eş değer toplam 1274 (her bir klima ortalama 182 saatten) saat çalıştırıldığı ve 4587 kWh enerji tükettiği tahmin edilmektedir. Klima kullanımının daha yoğun olduğu (soğutmalı depolar, sıcak gün sayısının fazla olduğu bölgeler vs.) işletmelerde bu maliyet kaleminin ağırlığı daha ciddi seviyelerde olacaktır. Uygulama örneğimizde tutar küçükte olsa örnek oluşturması açısından faaliyet tabanlı maliyetleme modeli analizimize dahil edilmiştir.

Fabrikanın iklimlendirilmesinde kullanılan fanlar soğuk günlerde üretim birimlerinin 1sıtılması için yazın iklimlendirme ve havalandırmanın sağlanması için kullanılmaktadır. Yazın fan motorları ile havalandırma sağlanırken kışın kalorifer kazanları devreye girerek 1sıtmayı sağlamaktadır. Fan motorlarının yıl boyunca çalışma saatleri içinde aktif olarak kullanıldığı bilinmektedir. Fan motorlarından kaynaklanan elektrik tüketim maliyeti 4.819,59 TL olmuştur. Bu hesaplamalar Tablo-3'te yer almaktadır.

\subsubsection{3. İmalat Makineleri}

Fabrikada 129 adet çeşitli elektrikli imalat makineleri bulunmaktadır. Elektrik tüketimleri veri olarak firmadan alınmıştır ve tüketimi $10 \mathrm{~kW}$ 'tan fazla olan (14 adet) büyük motorlu makineler faaliyetlere tahsis edilmiştir. İşletmeden bunlar arasında en çok elektrik tüketen makine $360 \mathrm{~kg}$ 'lık elektrik tüketimiyle yaş emaye ve boya pişirme işlemini gören tünel firındır. Fırının yıllık elektrik tüketimi 898.560 kws ve toplam elektrik maliyeti 254.112,77 TL ile enerji tüketiminde en fazla maliyete sahip ekipmandır. Fırın emaye pişirme işlemini 850 derecede yapmaktadır. Bu sıcaklığa ulaşmak için elektrik tüketimi ve maliyeti oldukça fazladır. Emaye bölümünde yıl boyu tam kapasite çalışan firın günde 8 saat ve ayda 26 gün çalışmaktadır.

Daha sonra lazer kesim makinesi 54 kW, 225 tonluk hidrolik baskı ve 400 tonluk çift pistonlu pres makineleri $37 \mathrm{~kW}$ ve diğer yüksek elektrik enerjisi ile çalışan imalat bölümü makineleri için ayrıca elektrik tüketim maliyetleri Tablo-4'te hesaplanmıştır. Çeşitli enerji maliyeti kategorisi, fotokopi makineleri, bilgisayarlar, temizlik ekipmanları ve diğer küçük ofis öğelerini içerir. Toplam enerji maliyetinin yaklaşık yüzde beşi olduğu tahmin 
edilmektedir ve 19.781,17 TL tutarındadır. Bu maliyet genel ofis faaliyetine tahsis edildi. Kalan enerji maliyeti 39.415,01 TL idi ki bu geriye kalan diğer enerji tüketen faaliyetin maliyeti olarak kabul edildi. Yani saat başına $10 \mathrm{~kW}$ enerjiden az tüketen diğer 115 üretim makinesi kullanımına tahsis edildi. Bu maliyet imalat katı faaliyetlerine dahil edilmesiyle imalat makinelerinin toplam enerji maliyeti 109.520,78 TL olmuştur.

\subsubsection{Kömür Tüketimi}

İşletmenin kalorifer bölümünde 3 adet kömürle çalışan yarım silindirik otomatik yüklemeli merkezi sistem kalorifer kazanları bulunmaktadır. Kazanların bir tanesi banyo bölümündeki havuzların 1sıtılması için sürekli çalışmaktadır. Diğer iki kazan fabrikanın ve yönetim ofisinin 1sıtılması için kullanılmaktadır. Diğer iki kazan fabrikanın ve yönetim ofisinin 1sıtılması için kullanılmaktadır. Sürekli çalışan kazanın günlük kömür tüketimi 250 $\mathrm{kg}$, diğer iki kazanın ise 6 ay boyunca günlük tüketimi 257,15'er kg'dır.

Havuzları 1sıtmak için birinci kazanın çalışması ile ilgili kömür tüketimine ait maliyet Emaye Bölümüne, ikinci ve üçüncü kazandan isınma amaçlı ortaya çıkan 52.253 TL'lik maliyet ise kullanım sürelerine göre diğer faaliyetlere aşağıdaki şekilde Tablo-5'de dağıtılmıştır:

- Depolama: Toplam Maliyetin \%10’u

- Yönetim Ofisi: Toplam Maliyetin \%20'si

- IImalat Kat1: Toplam Maliyetin \%70’i

Burada emaye bölümünde yer alan tünel firından çıkan sıcaklı̆ğın, bu bölümün kış aylarında istenilen sıcaklığı sağladığı göz önünde bulundurulduğundan maliyetlere yansıtılmamıștır. $\mathrm{Bu}$ adımdan sonra tüm kaynak maliyetlerinin faaliyet havuzlarına dağıtılmasını inceleyebiliriz (Tablo-6).

\subsubsection{Faaliyet Sürücülerinin Belirlenmesi}

Enerji maliyetleri ilk aşama dağıtım anahtarları kullanılarak her bir maliyet havuzuna tahsis edildikten sonra her faaliyet için ikinci aşama dağıtım anahtarları tanımlanmalıdır ve daha önce belirlenen sekiz maliyet merkezinin her birine dağıtımı yapılmalıdır. Her bir maliyet merkezi tarafından imalat alanının kullanımını doğru bir şekilde tanımlamak için makine saatleri kullanılmalıdır. Bu yüzden imalat ve emaye bölümü faaliyetlerinin maliyeti için makine saatleri maliyet sürücüsü kullanılmıştır. Depolama genellikle ürün hacmine dayanır. Depoculuk faaliyet maliyeti, her bir maliyet merkezinden geçen toplam hacime göre maliyet merkezlerine tahsis edilmiştir. Genel ofis faaliyet maliyetleri her zaman hacme dayalı olarak tahsis edilen organizasyon seviyesindeki maliyetleridir.

İşletme tarafından düzenli tutulan makine saatleri ve toplam üretim miktarları Tablo7'de yer almaktadır. En yüksek hacim 1.419.740 adet parçanın işlendiği Presleme bölümünde görülürken, en fazla makine saati 33.930 saat ile Dökümhane bölümünde yer almaktadır. Bu bölümde soba yapımında döküm olarak kullanılan küçük parçaların istenilen şekle getirilmesi için daha uzun bir süre işçi ve makine saati kullanılmaktadır. 


\subsubsection{Faaliyet Maliyetlerinin Maliyet Merkezine Dağıtılması}

Çalışmamızın başında, hem bilgi toplamanın maliyetini hem de hata olasılığını en aza indirgemek için enerji maliyetlerini tek tek ürünlere dağıtmak yerine sekiz maliyet merkezi belirlendiğine değinilmişti. Faaliyet oranlarının hesaplanması ve maliyet merkezine tahsisinde kullanılan yöntem ile dört faaliyet havuzundaki enerji maliyetlerinin dağıtım anahtarları ile sekiz maliyet merkezine tahsisleri Tablo-8'de gösterilmektedir.

FTM'nin bu uygulamadaki etkisini göstermek için, FTM tahsisini, geleneksel maliyet tahsisi ile elde edilecek tüm masrafların maliyet tahsisleri ile karşılaştırılacaktır. Üretimde otomasyona dayalı bir süreç olmadığından makine saatleri aynı zamanda her bir maliyet merkezi için çalışma saatlerini vermektedir. İşletmenin geleneksel yönteme göre takip ettiği enerji maliyeti tahsisi toplam enerji maliyetini çalışma saatlerine orantılı olarak dağıtılmasına dayanmaktadır (Tablo-9).

\begin{tabular}{cccc}
\hline $\begin{array}{c}\text { Maliyet } \\
\text { Merkezi }\end{array}$ & Geleneksel Maliyetleme & $\begin{array}{c}\text { Faaliyet Tabanlı } \\
\text { Maliyetleme }\end{array}$ & $\begin{array}{c}\text { FTM ile Arasindaki } \\
\text { \%'lik fark }\end{array}$ \\
\hline A) & $47.633,66 \mathrm{TL}$ & $45.522,95 \mathrm{TL}$ & $\% 4,64$ \\
B) & $77.801,64 \mathrm{TL}$ & $87.460,38 \mathrm{TL}$ & $-\% 11,04$ \\
C) & $63.511,54 \mathrm{TL}$ & $64.874,55 \mathrm{TL}$ & $-\% 2,10$ \\
D) & $48.427,55 \mathrm{TL}$ & $47.038,80 \mathrm{TL}$ & $\% 2,95$ \\
E) & $95.267,31 \mathrm{TL}$ & $90.262,66 \mathrm{TL}$ & $\% 5,54$ \\
F) & $39.694,71 \mathrm{TL}$ & $38.980,11 \mathrm{TL}$ & $\% 1,83$ \\
G) & $99.236,78 \mathrm{TL}$ & $95.492,18 \mathrm{TL}$ & $\% 3,92$ \\
H) & $35.725,24 \mathrm{TL}$ & $37.666,80 \mathrm{TL}$ & $-\% 5,15$ \\
\hline
\end{tabular}

Şekil 7. FTM ile Geleneksel Yöntemin Karşılaştırılması

$\mathrm{Bu}$ örnekte elde edilen nihai maliyet sonuçları, iki yöntem arasında, geleneksel yönteme kıyasla, FTM yöntemi için eksi yüzde on ila artı yüzde beş arasında değişen hatalarla büyük ölçüde farklılık göstermektedir. Bu geleneksel maliyetleme yönteminin önemli bir maliyet bozulması oluşturduğunu gösterecek kadar büyük bir farktır.

\subsection{Araştırmanın Bulguları}

İşletmenin enerji tüketimi faaliyet tabanlı maliyetleme yöntemi ile her bir maliyet merkezi için ayrıntılı olarak incelenmiştir. Uygulamadaki etkisini göstermek için FTM yöntemine göre yapılan maliyet dağıtılmış ve sonuçları geleneksel maliyet yöntemi ile karşılaştırılmıştır. Araştırmamız sonucu aşağıdaki bulgulara ulaşılmıştır.

- $\quad$ FTM yöntemi ile elde edilen maliyet verileri geleneksel yönteme kıyasla eksi yüzde onbir ila artı yüzde beş oranlarında değişen hatalarla büyük ölçüde farklılık göstermektedir. 
- $\quad$ FTM analizimiz sonucu dökümhane bölümünde üretim hacminin düşük olmasına rağmen enerji maliyetinin diğer birimlere oranla yüksek olduğu tespit edilmiştir.

- $\quad$ İşletme'nin banyo bölümünde gerçekleşen enerji tüketiminin oldukça yüksek olduğu saptanmıştır. Aynı sektörde doğalgaz enerjisini kullanan diğer işletmelerin enerji maliyetlerinde $\% 25$ ile $\% 30$ arasında tasarruf sağladığı bilinmektedir.

- $\quad$ İşletme yeniden tesisleşme aşamasında her ne kadar enerji verimli teknolojileri benimsemiş olsa da, enerji yönetiminde esas olan süreklilik ve devamlılık ilkesi ihmal edilmiştir.

Bu bulgular sonuç ve öneriler kısmında ayrıntılı olarak değerlendirilecektir.

\section{SONUÇ VE ÖNERILER}

Gittikçe artan enerji talebini karşılamak için kullanılan fosil kaynakların sınırlı olması ve çevreye olan olumsuz etkisi, insanları verimli enerji tüketimine, yenilenebilir enerjiye ve enerji yönetim sistemlerine yöneltmiş̧tir. Pazar lideri olmanın bir yolu, ürün maliyetlerini azaltmak ve böylece finansal verimliliği artırmaktır. Enerji, işletme maliyetlerini düşürmede kilit faktörlerden biridir.

Enerji tüketiminden kaynaklanan finansal ve ekolojik sonuçlar sistematik olarak gözden geçirilmeli analiz edilmeli ve iyileştirici stratejiler belirlenmelidir. Ancak elimizdeki verilerden yola çıkarak geldiğimiz noktada bu bakış açısının büyük ölçüde göz ardı edildiği görülmektedir. Aslında bu konunun önemi yakın geçmiş̧e enerji maliyeti üzerine yapılan araştırmalarda vurgulanmış olsa da enerji israfını, tüketimin maliyetini ve enerji verimliliği boşluğunun sonuçlarını açık ve görülebilir kılan muhasebe tekniklerini içeren çalışmalar çok sınırlı kalmıştır.

Bir kuruluşun enerji tüketimini en uygun hale getirmek için enerji tüketimini artıran bireysel değişkenlerin rolü sadece nitelik değil aynı zamanda nicelik olarak da bilinmelidir. $\mathrm{Bu}$ amaçla maliyet muhasebesinin yeni kavramlarından biri olan FTM modeli bu önemli girdinin yönetilmesi mümkün kılmakta ve karar vericilere önemli bilgiler sunmaktadır.

Üretim işletmesinde yaptığımız enerji denetimi sonucu yeni tesis kurulum aşamasında alınan tedbirlerin aydınlatma, ssıtma ve soğutma gibi enerji tüketiminin fazla olabileceği alanlarda yüksek oranda enerji tasarrufu sağladığ 1 görülmüştür. Diğer taraftan enerji maliyetlerinin FTM yöntemine göre analizi sonucu elde ettiğimiz maliyet verileri, geleneksel yönteme kıyasla daha doğru ve ayrıntılı bilgiler sağlamıştır.

Araştırmamız sonucu elde edilen bulgular ışığında aşağıdaki tedbirlerin alınması önerilmektedir:

- Geleneksel yönteme göre tahsis edilen enerji masraflarının önemli bir maliyet bozulması oluşturduğu tespit edilmiştir. Finansal verilerin yanlış olduğu bir işletmede doğru kararlar vermek imkansızdır. İşletmeler için kritik bir girdi olan enerji maliyetlerinin FTM modeli ile analizi gerçek maliyet verileri üzerinden doğru kararlar almalarına, enerji tüketimine neden olan faktörlerin belirlenmesine, enerjiyi akılcı ve verimli kullanmalarına, rekabetçi pozisyonlarını iyileştirmelerine ve karlılığa önemli derecede katkı sağlar. 
- $\quad$ Enerji maliyet tahsisinde en yüksek paya sahip olan maliyet merkezi dökümhane birimi olmuştur. Bu birimin modernizasyonu için yeni bir döküm makinesinin alınması durumunda yatırımın fizibilitesini değerlendirmemize olanak sağlayacak FTM verilerinden yararlanılabilir.

Hâlihazırda doğalgaz enerjisine erişimi mümkün olmayan işletmenin elektrik ihtiyacını karşılamak için alternatif enerji kaynaklarını değerlendirebilir. Devlet tarafından sağlanan Güneş Enerjisi Santrali (GES) teşviklerinden de yaralanarak işletme ihtiyaç duyduğu enerjiye kesintisiz erişim sağlayabilir.

- Enerji verimliliğinde sürekliliğin sağlanması açısından enerji yönetimi programını geliştirmek ve sürdürmek için programın koordinasyonundan sorumlu bir kişinin (enerji yöneticisi) atanması önerilmektedir. 'Özel' bir enerji yöneticisi istihdam edilmesi, personel maliyetine neden olabileceğinden orta ölçekli bu işletme için üretim müdürü veya tesis yöneticisi, enerji ile ilgili faaliyetlerden sorumlu tutulabilir.

Genel olarak elde edilen bulgular çerçevesinde, üretim süreçlerine ait enerji ile ilgili tüketim ve kayıpların belirlenmesi ve analiz edilmesinde kullanılan FTM yönteminin, uygulamadaki anormalliklerin hılı bir şekilde tespit edilmesine olanak sağladığı görülmektedir. Karar vericilere sunduğu bu veriler çerçevesinde enerji israflarını azaltmak, maliyetleri en aza indirerek karlılığ tüketiminden kaynaklanan çevresel sorunların azaltılmasına da katkı sağlar. Böylelikle işletmeler enerji odaklı bakış açısı geliştirerek uzun dönemde rekabetçi pozisyonlarını iyileştirmeleri için etkin ve akılcı stratejiler geliştirebilirler.

FTM sistemleri çok kullanışlı olsa da tüm şirketler tarafından kullanılması uygun olmayabilir. Yöntemin uygulama masrafları ve faaliyetlerin takibi çok pahalı olabilir. Bir şirket sistemden elde edilen bilgiler ile sağlayacağı maliyet tasarrufu ile uzun vadede sistemin uygulanması ve yönetilmesi için gereken maliyeti karşılaştırmalıdır. Sağlanan maliyet tasarrufu daha fazla olacağı öngörüldüğü zaman bir FTM sistemini uygulamalıdır. Hızla gelişen teknolojiyle birlikte karmaşı bir FTM sistemi uygulamak daha ekonomik hale gelmektedir. Bu koşullarda bazı kurumsal firmalar yatırımlarını yapmaktadır ancak büyük bir enerji sistemi dönüşümü yaratmak için daha birçok firma yenilikçi mekanizmalar ve yaygınlaştırıcı politikalar ile desteklenmelidir.

Çalışmada ele alınan enerji analizleri sonucu performans göstergelerine, ölçütlere ve verimlilik hedeflerine odaklanan enerji yönetimine yönelik organizasyonel planlama yapılması ve uzun vadeli stratejilerin belirlenmesi tavsiye edilmektedir. Aynı zamanda enerji yönetimi ve muhasebe sistemlerinin kullanımı ile çevre bilincini ve örgüt kültürünün gelişimine de katkı sağlanması beklenmektedir.

\section{KAYNAKLAR}

A.E.Eagles - J.Claret. (1990), Energy Accounting for Smaller Companies, (The Watt Committee The Watt Committee), Evaluation of Energy Use. London: CRC Press, pp. 8-11.

A.Melvin - J.W.Bryant - M.H.Cadman - P.A.Hazzard. (1990), Concepts of Energy Analysis and Energy Accounting. (Watt Committee Watt Committee), Evaluation of Energy Use. London: CRC Press, pp. 14-16. 
Annett, Bierer - Uwe, Götze (2012), "Energy Cost Accounting: Conventional and FlowOriented Approaches", Journal of Competitiveness, Vol. 4, No. 2, pp. 128-144.

ASRAE (2015), Energy Use and Management, (Inch-Pound Edition), Atlanta, Ga, American Society of Heating, Refrigerating and Air-Conditioning Engineers.

Boyles, Jesse V (1979), "Energy Accounting", Management Accounting (pre-1986), Vol. 60, No. 8, pp. 35-42.

Bozkurt, İbrahim - Karataş, Muharrem (2011), "Türkiye'deki Yenilenebilir Enerji Sektörünün Muhasebe Sorunları", Mali Çözüm, Sayı 107, Eylül-Ekim, ss. 85-116.

California Energy Commision (2000), Energy Accounting: A Key Tool in Managing Energy Costs, (2nd Ed.), California, California Energy Commision.

Capehart, Barney L. - Turner, Wayne C. - Kennedy, William J. (2003), Guide to Energy Management, Lilburn, Fairmont Press, Inc.

Cornwall, Bonnie J. - California Energy Extension Service, Sacramento (1984), How to Organize and Communicatre Your Energy Data. A Guide to Energy Accounting.

Çakal, Ender (2006), Tarım Makinaları İmalatında Enerji Yönetimi Üzerine Bir Araştırma, (Yüksek Lisans Tezi), Trakya Üniversitesi, Trakya.

Davis, Charles E. - Davis, Elizabeth (2013), Managerial Accounting, (2nd Edition), Hoboken, Wiley.

Dizkırıcı, Ahmet Selçuk (2012), Konutlarda Enerji Verimliliğinin Ölçümü Için 5-Yııldılı Derecelendirme Sistemi Ve Ekonometrik Uygulama, (Doktora Tezi), Sakarya Üniversitesi, Sakarya.

Dury, Colin (2018), Management and Cost Accounting, (10th Edition), Hampshire, Cengage Learning.

Elektrik İşleri Etüt İdaresi Genel Müdürlüğü, Enerji Yönetimi Prensipleri. www.deneysan.com/Content/images/documents/ey-04_63702254.pdf, Erişim Tarihi: 16.03.2018.

ETSU - Harwell - Didcot - Oxfordshire - ORA, OX11. (1999). Energy in Plastics Processing a Practical Guide. http://www.tangram.co.uk/TIEnergy_in_Plastics_Processing_(GPG292).pdf, Accessed: 19.03.2018.

Fernandes, J. Michael - Capehart, Barney L. - Capehart, Lynne C. (1997), "Allocation of Energy Costs in Manufacturing Using Activity-Based Costing", Energy Engineering, Vol. 94, No. 4, pp. 17-33.

Garrison, Ray H. - Noreen, Eric W. - Brewer, Peter C. (2018), Managerial Accounting, (16th Edition), New York, McGraw-Hil. 
Henze, Gregor P. (2001), "Building Energy Management as Continuous Quality Control Process", Journal of Architectural Engineering, Vol. 7, No. 4, pp. 97-106.

Hofmann, E. - Bosshard, J. (2017), "Supply Chain Management and Activity-Based Costing Current Status and Directions for the Future", International Journal of Physical Distribution \& Logistics Management, Vol. 47, No. 8, pp. 712-735.

Horngren, Charles t. - Datar, Srikant M. - Rajan, Madhav V. (2015), Cost Accounting, (15th Edition), Essex, Pearson.

Hyman, Leonard S. (1976), "Utility Accounting and Energy Policy", Science, Vol. 194, No. 4271, pp. 1226-1228.

J.K.Jacques - J.C.R.Hewgill - M.Cadman. (1990). Measurement and Planning for Energy Audit and Energy Accounting (Watt Committee Watt Committee), Evaluation of Energy Use. CRC Press, pp.

Karsl1, Süleyman - Güllüce, Hüseyin - Saraç, Hanifi. (2011). "Isıtma ve Soğutma Sistemlerinde Enerji Maliyetlerinin Karşılaştırılması", Ulusal İklimlendirme Kongresi, Antalya.

Kavak, Kubilay. (2005), Dünya'da ve Türkiye'de Enerji Verimliliği ve Türk Sanayiinde Enerji Verimliliğinin İncelenmesi, (DPT Uzmanlık Tezi Uzmanlık Tezi), DPT, Ankara.

Kim, Yong-Woo (2017), Activity Based Costing for Construction Companies, Chichester, John Wiley \& Sons.

Kırlı, Mustafa - Kulu, Tekmez (2016), "Enerji Yönetimi ve Enerji Muhasebesi", Journal of Human Sciences, Sayı. 13, Cilt. 3, ss. 4891-4905.

Nelson, K. E. (1994), "A Practical Guide to Energy Accounting 1.", Chemical Engineering, Vol. 101, No. 9, pp. 122-128.

Schulze, Mike - Nehler, Henrik - Ottosson, Mikael - Thollander, Patrik (2016), "Energy Management in Industry - a Systematic Review of Previous Findings and an Integrative Conceptual Framework", Journal of Cleaner Production, Vol. 112, pp. 3692-3708.

Smith, Craig B. - Parmenter, Kelly E. (2016). Energy Management Principles. http://proquestcombo.safaribooksonline.com/book/energy/9780128026441, Erişim Tarihi: 25.01.2018.

Sygulla, R. - Bierer, A. - Götze, U. (2011), Material Flow Cost Accounting - Proposals for Improving the Evaluation of Monetary Effects of Resource Saving Process Designs. Paper presented at the The 44th CIRP Conference on Manufacturing Systems, Madison, Wisconsin, USA.

Tangram (2010), Accounting for Energy Efficiency. http://www.tangram.co.uk/TI-EnergyThere's_no_accounting_for_energy_efficiency.html, Accessed: 19.03.2017. 
Thollander, Patrik - Palm, Jenny (2013), Managing Energy Efficiency in Industry: Theory and Practice. Improving Energy Efficiency in Industrial Energy Systems. pp. 85-104.

Topall1, Nurgün (2012), Enerji Etkinliği Ve Türkiye'de Konut Elektriği Tüketiminin Geri Tepme (Rebound Effect) Etkisi, (Doktora Tezi), Selçuk Üniversitesi, Konya.

Tripp, Douglas E. (2007), Accounting: Facility Energy Use. (Barney L. Capehart Barney L. Capehart), Encyclopedia of Energy Engineering and Technology. Boca Raton: CRC Press, pp. 1-8.

Turner, Wayne C. (2001), Energy Management Handbook, (4 ${ }^{\text {th }}$ Edition), Lilburn, The Fairmont Press.

Unutkan, Özcan (2010), "Faaliyet Tabanli Maliyet Sistemi ve Bir Uygulama", Mali Çözüm, Sayı 97, Ocak-Şubat, ss. 87-105.

Ü̧̧üncü, Kemal. (2016), Enerji Yönetimi Ders Notları, Karadeniz Teknik Üniversitesi, Trabzon,www.aves.ktu.edu.tr/ImageOfByte.aspx?Resim=8\&SSNO=154\&USER=404 9, Erişim Tarihi:13/02/2017.

Wang, Qiuhong (2013), "Study on Energy Conservation and Consumption Reduction", Applied Mechanics and Materials, Vol. 329, pp. 36-39.

Xiang, Y. - Liu, J. Y. - Yang, W. - Huang, C. (2015), "Active Energy Management Strategies for Active Distribution System", Journal of Modern Power Systems and Clean Energy, Vol. 3, No. 4, pp. 533-543. 


\section{EKLER: Hesaplama Tabloları}

Tablo 1. İşletmenin 2017 Y1lı için Enerji Tüketimleri ve Maliyetleri

\begin{tabular}{llll} 
Enerji Türü & 2017 Maliyet & 2017 Tüketim & Birim Maliyet \\
\hline Elektrik & $395.623,44 \mathrm{TL}$ & $1.398 .884,76 \mathrm{kWh}$ & $0,2828 \mathrm{TL} / \mathrm{kWh}$ \\
Kömür & $111.675,00 \mathrm{TL}$ & $171.480,00 \mathrm{~kg}$ & $0,6512 \mathrm{TL} / \mathrm{kg}$
\end{tabular}

Tablo 2. Aydinlatma Maliyetleri Hesaplama Tablosu

\begin{tabular}{|c|c|c|c|c|c|c|c|c|}
\hline Alan & $\begin{array}{c}\text { Lamba } \\
\text { Türü }\end{array}$ & Watt & Sayısı & $\begin{array}{c}\text { Balast } \\
\text { Kullanım }\end{array}$ & $\begin{array}{c}\text { Toplam } \\
\text { Watt }\end{array}$ & $\begin{array}{l}\text { Yıllık } \\
\text { Saati }\end{array}$ & $\begin{array}{c}\text { Enerji } \\
\text { kWh }\end{array}$ & $\begin{array}{c}2017 \\
\text { Maliyet }\end{array}$ \\
\hline İmalat Katı & $\begin{array}{c}\mathrm{HO} \\
54 \mathrm{~W} / 865\end{array}$ & 54 & 331 & 0,2 & 21.448 & 578 & 12.393 & $\begin{array}{c}3.504,74 \\
\text { TL }\end{array}$ \\
\hline $\begin{array}{l}\text { Emaye } \\
\text { Bölümü }\end{array}$ & $\begin{array}{c}\mathrm{HO} \\
54 \mathrm{~W} / 865\end{array}$ & 54 & 83 & 0,2 & 5.378 & 624 & 3.356 & $949,11 \mathrm{TL}$ \\
\hline Depolama & $\begin{array}{c}\mathrm{HO} \\
54 \mathrm{~W} / 865\end{array}$ & 54 & 117 & 0,2 & 7.582 & 220 & 1.668 & $471,70 \mathrm{TL}$ \\
\hline $\begin{array}{l}\text { Genel Ofis } \\
\text { (İdari) }\end{array}$ & $\begin{array}{c}\text { TL-D } \\
18 \mathrm{~W} / 54-765\end{array}$ & 18 & 144 & 0,2 & 3.110 & 936 & 2.911 & $823,33 \mathrm{TL}$ \\
\hline $\begin{array}{l}\text { Genel Ofisi } \\
\text { (Yönetim) }\end{array}$ & $\begin{array}{l}\text { Led Panel } \\
30 * 120\end{array}$ & 54 & $24 \mathrm{~m}$ & - & 1.296 & 936 & 1.213 & $343,05 \mathrm{TL}$ \\
\hline
\end{tabular}

\section{$\underline{\text { Klima Enerji Tüketimi Hesaplama }}$}

Tüketilen Enerji $=3,6 \mathrm{~kW} \times 1274$ saat $=4587 \mathrm{~kW}$

Maliyet $=4587 \mathrm{~kW} \times 0,2828 \mathrm{TL}=1.297,20 \mathrm{TL}$

Tablo 3. İşletmenin Fan Motorları için Enerji Tüketimi ve Maliyeti

\begin{tabular}{lccccc}
$\begin{array}{c}\text { Faaliyet } \\
\text { Alanları }\end{array}$ & $\begin{array}{c}\text { Fan } \\
\text { Sayı1 }\end{array}$ & $\begin{array}{c}\text { Çalışma } \\
\text { Süresi }\end{array}$ & $\begin{array}{c}\text { Fan Motoru } \\
\text { Elektrik } \\
\text { Tüketimi }\end{array}$ & $\begin{array}{c}\text { Enerji } \\
\text { Tüketimi }\end{array}$ & Maliyet \\
\hline İmalat Katı & 19 & 1872 & 0,27 & 2527 & $2.715,83 \mathrm{TL}$ \\
\hline $\begin{array}{l}\text { Emaye } \\
\text { Bölümü }\end{array}$ & 7 & 2496 & 0,27 & 4717 & $1.334,09 \mathrm{TL}$ \\
\hline Depolama & 7 & 1440 & 0,27 & 2722 & $769,67 \mathrm{TL}$ \\
\hline \multicolumn{1}{c}{ Toplam } & 33 & & & & $4.819,59 \mathrm{TL}$ \\
\hline
\end{tabular}


Tablo 4. Üretim Makinelerinin Enerji Kaynak Maliyetinin Hesaplanmas1

\begin{tabular}{|c|c|c|c|c|}
\hline Ekipmanlar & $\begin{array}{c}\text { Enerji } \\
\text { Tüketimi } \\
(\mathbf{k W})\end{array}$ & $\begin{array}{l}\text { Yillık } \\
\text { Çalışma } \\
\text { Saati }\end{array}$ & $\begin{array}{l}\text { Toplam Enerji } \\
\text { Tüketimi (kWh) }\end{array}$ & $\begin{array}{c}\text { Toplam Maliyeti } \\
\text { (TL) }\end{array}$ \\
\hline Lazer Kesme Makinesi & 54 & 1248 & 67392 & $19.058,46 \mathrm{TL}$ \\
\hline Hidrolik Pres 225 Tonluk & 37 & 546 & 20202 & $5.713,13 \mathrm{TL}$ \\
\hline Hidrolik Pres 400 Tonluk Çift Pistonlu & 37 & 546 & 20202 & $5.713,13 \mathrm{TL}$ \\
\hline Hidrolik Pres 200 Tonluk Çift Pistonlu & 30 & 546 & 16380 & $4.632,26 \mathrm{TL}$ \\
\hline Hidrolik Pres 200 Tonluk & 30 & 546 & 16380 & $4.632,26 \mathrm{TL}$ \\
\hline Hidrolik Pres 300 Tonluk & 30 & 546 & 16380 & $4.632,26 \mathrm{TL}$ \\
\hline Hidrolik Pres 300 Tonluk & 30 & 546 & 16380 & $4.632,26 \mathrm{TL}$ \\
\hline Hidrolik Pres 300 Tonluk & 22 & 546 & 12012 & 3.396,99 TL \\
\hline Abkant Pres Makinesi & 22 & 1170 & 25740 & $7.279,27 \mathrm{TL}$ \\
\hline Robot & 21 & 234 & 4914 & $1.389,68 \mathrm{TL}$ \\
\hline Hidrolik Pres 120 Tonluk & 20 & 546 & 10920 & $3.088,18 \mathrm{TL}$ \\
\hline Hidrolik Pres 100 Tonluk & 15 & 546 & 8190 & $2.316,13 \mathrm{TL}$ \\
\hline Hidrolik Pres 120 Tonluk & 15 & 546 & 8190 & $2.316,13 \mathrm{TL}$ \\
\hline Vinç 15 Tonluk Köprülü & 14,75 & 313 & 4616,75 & $1.305,62 \mathrm{TL}$ \\
\hline
\end{tabular}

Yüksek Elektrik Tüketimine Sahip İmalat Makineleri:

TET $=$ ET $*$ YÇS

Toplam Maliyet $=$ TET $* 0,2828 \mathrm{TL} / \mathrm{kWh}$

TET $=$ Toplam Enerji Tüketimi

YÇS $=2017$ yılı boyunca ekipmanın toplam çalışma saatleri

Ceșitli Kullanım:

Toplam Maliyetin $\% 5=0,05 * 395.623,44=19.781,17 \mathrm{TL}$

Diğer Üretim Makineleri:

Geriye kalan maliyet $=39.415,01 \mathrm{TL}$

$\mathrm{Bu}$ makinelerin toplam enerji maliyeti ise 70.105,77 TL olmuştur 
Tablo 5. Y1llık Kömür Tüketimi Hesaplaması

\begin{tabular}{cccccc} 
Kazan No & $\begin{array}{c}\text { Günlük } \\
\text { Tüketim } \\
(\mathbf{k g})\end{array}$ & $\begin{array}{c}\text { Yıllık } \\
\text { Tüketim } \\
\text { Süresi* }\end{array}$ & $\begin{array}{c}\text { Toplam } \\
\text { Tüketim } \\
(\mathbf{k g})\end{array}$ & $\begin{array}{c}\text { Kömürün } \\
\text { kg Fiyatı } \\
(\mathbf{k g} / \mathbf{T L})\end{array}$ & $\begin{array}{c}\text { Toplam } \\
\text { Maliyet } \\
\text { (TL) }\end{array}$ \\
\hline 1. Kazan & 250 & 365 & 91250 & 0,6512 & 59.422 \\
2. Kazan & 257,17 & 156 & 40119 & 0,6512 & $26.126,50$ \\
3. Kazan & 257,17 & 156 & 40119 & 0,6512 & $26.126,50$ \\
\hline * 1. Kazan hiç söndürülmeden 365 gün çalışmakta diğer kazanlar ise kişın 6 ay boyunca günde 8 saat \\
çalıştırılmaktadır
\end{tabular}

Tablo 6. Enerji Maliyetlerinin Faaliyet Havuzlarına Tahsisi

Depolama Faaliyeti Maliyet Havuzu

\begin{tabular}{lc} 
Dağıtım & Maliyet \\
\hline Aydınlatma & $471,70 \mathrm{TL}$ \\
Isıtma (Isınma Maliyetinin \%10’i) & $5.225,30 \mathrm{TL}$ \\
Soğutma ve İklimlendirme & $769,67 \mathrm{TL}$ \\
\hline Toplam & $\mathbf{6 . 4 6 6 , 6 7 ~ T L}$ \\
İmalat Katı Faaliyeti Maliyet Havuzu & \\
\hline Dağıtım & Maliyet \\
\hline Aydınlatma & $3.504,74 \mathrm{TL}$ \\
Isıtma (Isınma Maliyetinin \%70’i) & $36.577,10 \mathrm{TL}$ \\
Soğutma ve İklimlendirme & $2.715,83 \mathrm{TL}$ \\
İmalat Makineleri & $109.520,78 \mathrm{TL}$
\end{tabular}

\begin{tabular}{ll}
\hline Toplam & $152.318,45 T L$
\end{tabular}

$\underline{\text { Yönetim Ofisi Faaliyeti Maliyet Ofisi }}$

Dağıtım Maliyet

Aydınlatma $1.166,38 \mathrm{TL}$

Isitma (Isinma Maliyetinin \%15'i) $\quad 10.450,60 \mathrm{TL}$

Çeşitli Giderler $\quad 19.781,17$ TL

Klima $\quad 1.297,20 \mathrm{TL}$

\begin{tabular}{ll}
\hline Toplam & 32.695,35 TL
\end{tabular}

Emaye Faaliyeti Maliyet Havuzu

$\begin{array}{lr}\text { Dağıtım } & \text { Maliyet }\end{array}$

Aydınlatma 949,11 TL

Isitma (Havuz Isitma Maliyeti) $\quad 59.422 \mathrm{TL}$

Soğutma ve İklimlendirme $\quad 1.334,09 \mathrm{TL}$

İmalat Makineleri $\quad 254.112,77 \mathrm{TL}$ 
Tablo 7. İkinci Aşama Maliyet Sürücüleri Bilgileri

\begin{tabular}{|l|c|c|}
\hline \multicolumn{1}{|c|}{ Maliyet Merkezleri } & Toplam Makine Saatleri & Toplam Hacim \\
\hline A) Sac Kesim & 16.286 & 141.974 \\
\hline B) Presleme & 26.601 & 1.419 .740 \\
\hline C) Puntalama & 21.715 & 567.896 \\
\hline D) Banyo & 16.558 & 212.961 \\
\hline E) Emaye Kaplama & 32.572 & 212.961 \\
\hline F) Firınlama & 13.572 & 212.961 \\
\hline G) Dökümhane & 33.930 & 354.935 \\
\hline H) Montaj & 12.215 & 425.922 \\
\hline \multicolumn{1}{|c|}{ TOPLAM } & 173.448 & 3.549 .350 \\
\hline \multicolumn{2}{|c|}{} \\
\hline
\end{tabular}

Tablo 8. Faaliyet Merkezlerinin Maliyet Objelerine Dağıtılması

\begin{tabular}{|c|l|l|l|l|l|}
\hline Maliyet Merkezi & \multicolumn{1}{|c|}{ İmalat Katı } & Emaye Bölümü & \multicolumn{1}{|c|}{ Depolama } & \multicolumn{1}{|c|}{ Yönetim Ofis } & Toplam \\
\hline $\mathrm{A}$ & $14.302,20 \mathrm{TL}$ & $29.654,27 \mathrm{TL}$ & $258,67 \mathrm{TL}$ & $1.307,81 \mathrm{TL}$ & $45.522,95 \mathrm{TL}$ \\
\hline $\mathrm{B}$ & $23.360,26 \mathrm{TL}$ & $48.435,31 \mathrm{TL}$ & $2.586,67 \mathrm{TL}$ & $13.078,14 \mathrm{TL}$ & $87.460,38 \mathrm{TL}$ \\
\hline $\mathrm{C}$ & $19.069,60 \mathrm{TL}$ & $39.539,03 \mathrm{TL}$ & $1.034,67 \mathrm{TL}$ & $5.231,26 \mathrm{TL}$ & $64.874,55 \mathrm{TL}$ \\
\hline $\mathrm{D}$ & $14.540,57 \mathrm{TL}$ & $30.148,51 \mathrm{TL}$ & $388,00 \mathrm{TL}$ & $1.961,72 \mathrm{TL}$ & $47.038,80 \mathrm{TL}$ \\
\hline $\mathrm{E}$ & $28.604,40 \mathrm{TL}$ & $59.308,54 \mathrm{TL}$ & $388,00 \mathrm{TL}$ & $1.961,72 \mathrm{TL}$ & $90.262,66 \mathrm{TL}$ \\
\hline $\mathrm{F}$ & $11.918,50 \mathrm{TL}$ & $24.711,89 \mathrm{TL}$ & $388,00 \mathrm{TL}$ & $1.961,72 \mathrm{TL}$ & $38.980,11 \mathrm{TL}$ \\
\hline $\mathrm{G}$ & $29.796,25 \mathrm{TL}$ & $61.779,73 \mathrm{TL}$ & $646,67 \mathrm{TL}$ & $3.269,54 \mathrm{TL}$ & $95.492,18 \mathrm{TL}$ \\
\hline $\mathrm{H}$ & $10.726,65 \mathrm{TL}$ & $22.240,70 \mathrm{TL}$ & $776,00 \mathrm{TL}$ & $3.923,44 \mathrm{TL}$ & $37.666,80 \mathrm{TL}$ \\
\hline Toplam & $152.318,45 \mathrm{TL}$ & $315.817,97 \mathrm{TL}$ & $6.466,67 \mathrm{TL}$ & $32.695,35 \mathrm{TL}$ & $507.298,44 \mathrm{TL}$ \\
\hline
\end{tabular}

\section{Faalivet Oranlarının Hesaplaması}

Faaliyet Oran $1=($ Makine Saati $/$ Toplam Saat $)$

Maliyet Merkezi $=$ Faaliyet Oran 1 T Toplam Depolama Maliyeti

İmalat ve Emaye Bölümü $=($ MS/TMS $) *$ FMH

$\mathrm{FMH}=$ Faaliyet Maliyet Havuzu

Yönetim Ofisi, Depolama Alanı $=(\mathrm{H} / \mathrm{TH})^{*} \mathrm{FMH}$

$\mathrm{H}=$ Hacim

$\mathrm{TH}=$ Toplam Hacim

FMH $=$ Faaliyet Maliyet Havuzu 
Tablo 9. Geleneksel Yönteme Göre Firmanın Enerji Maliyet Tahsisi

\begin{tabular}{|c|c|c|c|}
\hline & Maliyet Merkezi & Toplam Makine Saatleri & Enerji Maliyetleri \\
\hline A) & Sac Kesim & 12769 & $47.633,66 \mathrm{TL}$ \\
\hline B) & Presleme & 25538 & 77.801,64 TL \\
\hline C) & Puntalama & 25538 & $63.511,54 \mathrm{TL}$ \\
\hline D) & Banyo & 12769 & $48.427,55 \mathrm{TL}$ \\
\hline E) & Emaye Kaplama & 25538 & $95.267,31 \mathrm{TL}$ \\
\hline F) & Firınlama & 10641 & 39.694,71 TL \\
\hline G) & Dökümhane & 51077 & $99.236,78 \mathrm{TL}$ \\
\hline $\mathrm{H})$ & Montaj & 9577 & $33.725,24 \mathrm{TL}$ \\
\hline & TOPLAM & 173448 & $507.298,44 \mathrm{TL}$ \\
\hline
\end{tabular}


